\title{
Lietuvos istorijos mokslo ir studiju transformacija 1988-1990 metais pagal institucijų posėdžių protokolus
}

\author{
VALDAS SELENIS \\ Lietuvos edukologijos universitetas, T. Ševčenkos g. 31, LT-03111 Vilnius \\ El. paštas valdas.selenis@leu.lt
}

\begin{abstract}
Straipsnyje aptariama Lietuvos istorijos mokslo transformacija vaduojantis iš ideologinių klišių, primestos dirbtinès marksistinès metodologijos „lūžio“ - Sajūdžio ir Atgimimo 1988-1990 m. - laikotarpiu. I šią transformaciją žvelgiama iš akademinių instituciju „vidaus“ - tyrimui panaudoti Vilniaus universiteto Istorijos fakulteto, Lietuvos istorijos instituto mokslinių tarybų ir Partijos istorijos instituto bei Vilniaus pedagoginio instituto Lietuvos istorijos katedros posèdžių protokolai.

Raktažodžiai: istorijos mokslas, Sąjūdis, Atgimimas, istorikai, Vilniaus universiteto Istorijos fakultetas, Lietuvos istorijos institutas, Partijos istorijos institutas, Vilniaus pedagoginio instituto Lietuvos istorijos katedra, posèdžių protokolai
\end{abstract}

\section{IVADAS}

Atgimimo, arba Sąjūdžio laikotarpis 1988-1990 m. yra vienas iš reikšmingiausių „lūžio“ momentų Lietuvos istorijoje. Keičiantis santvarkoms, atsilaisvinant ideologiniams „varžtams“ turejjo keistis ir istorijos mokslas - atejo apsivalymo nuo privalomų "marksistinių“ standartų metas. Šias problemas po truputị pradejo liesti tuos laikus gerai prisimenantys istorikai. Alfonsas Eidintas konstatuoja, kad 1988 metai iš esmès sunaikino visuotinai kritikuojamą sovietinę istoriją ir pradejo naujos istorijos rašymą, tačiau šokti ị diskusijų verpetą visam istorikų klanui tam tikra prasme trukdè ir grynai dèl atsargumo „ikalti profesiniai ribotumai“ - t. y. „neišeiti“ už savo tyrinèjamos tematikos ribų, turèti didelį įdirbị ir užsikariautą autoritetą toje srityje $[2,36]$. Ideologiniai primesto istorijos tyrimo metodai ne vienam apkartino gyvenimą, ir tie atsiminimai gana slogūs ir sunkūs: „Ne vieną stabdo gal ir tai, jog šiandien bandyti nagrinèti 1987-1990 metų istorijos mokslo situaciją atrodo ir per anksti esant daryti, - dar nedidelè laiko distancija skiria mus nuo tų ypatingos svarbos visai tautai ir valstybei ịvykių <...> “ $[2,9-10]$.

Kita vertus, yra pavojus, kad apie lemtingus istorijos įvykius bus pradèta kalbèti per vèlai - daug kas greitai užsimiršta ir dingsta. Mokslo institucijose tuo metu dirbo pusketvirto šimto istorikų [31]. Savotišku politinio persitvarkymo ir tautinio atgimimo idejuc židiniu pirmiausia buvo tapęs Puslaidininkių fizikos institutas, kurio dauguma darbuotojų aktyviai 
prisidèjo prie Sąjūdžio ịkūrimo. Istorijos institutą (toliau - II) pertvarkos idèjos pasiekè vèliau, perestroikai priartejus prie Lietuvos, istorija tapo pačia aktualiausia ir jautriausia viešo gyvenimo sritimi. Česlovo Laurinavičiaus ir Vlado Sirutavičiaus nuomone, $1987 \mathrm{~m}$. V. Merkio ir A. Eidinto tandemas reprezentavo tuometès Lietuvos visuomenès mini modeli, paradoksaliai jungiantị ir nepriklausomos, ir sovietinès Lietuvos paveldą. Tačiau tas sujungimas buvo mechaninis. V. Merkys su A. Eidintu daug prisidejo prie to, kad Lietuvos viešajame diskurse 1918-1920 m. ir 1939-1940 m. ịvykiai būtų pamažu, bet kryptingai pradèti vertinti objektyviai ir kad istorinis vertinimas atitiktų Lietuvos nacionalinius interesus [8].

Kai kurie istorikai tapo aktyviais Sąjūdžio dalyviais. 1988 m. rugsẻjo 15 d. dalyvaujant Vilniaus Sąūdžio rèmimo grupių atstovams, buvo išrinkta pirmoji Lietuvos Persitvarkymo Sąūdžio Vilniaus Taryba ir aktyvas. Nariais tapo istorikai Artūras Andriušaitis, Alfonsas Būčys, Alfredas Bumblauskas, Gediminas Rudis, Liudas Truska [37].

Apie istoriją ir istorikus tuo lūžio laikotarpiu pirmasis rašè Alfredas Erichas Sennas [38], kuris tų metų vasarą ir rudenị lankèsi Lietuvoje kaip Lietuvos mokslų akademijos Istorijos instituto svečias, vèliau - Č. Laurinavičius [8], L. Truska [39], A. Eidintas [2] ir Vilius Ivanauskas [7]. Pastarojo parašyta kolektyvinès monografijos apie Sąjūdị dalis yra artimiausia šio straipsnio temai. V. Ivanauskas, apklausęs tuometinėse akademinèse institucijose dirbusius istorikus, išskyrè II dirbusius istorikus Juozą Jurginị, Antaną Tylą, G. Rudị, Vytautą Žalị, A. Eidintą, Ingę Lukšaitę, Zigmantą Kiaupą, Edvardą Gudavičių, Mečislovą Jučą, V. Merkį, etnologus Angelę Vyšniauskaitę ir Vacị Milių, archeologę Rimutę Rimantienę ir savo straipsnị apibendrino teigdamas, kad dalis Sąūdžio iškeltų istorikų brendo ir savo nuostatas kūrè išgyvendami ilgalaikę trintị su sistema, kitiems kritiškumas buvo perestroikos laikų atradimas, treti atsiskleidè kaip laviruojantys mokslininkai [7, 143, 146, 148].

Straipsnio tikslas - išryškinti, kokias transformacijas fiksavo aptariamojo laikotarpio istorijos akademinès institucijos, ir palyginti situaciją atskirose institucijose. Šiam tikslui pasiekti panaudoti oficialūs šaltiniai - mokslo ir studijų institucijų (universiteto, institutų) tarybų posėdžių protokolai ir kai kurie skelbti atsiminimai [3]. Jie leidžia palyginti, kaip istorijos mokslo transformaciją vertino tuo metu tose institucijose dirbę istorikai. Posedžių protokolai yra oficialūs dokumentai, todèl ị juos patekdavo tik nuotrupos „užkulisinès“ informacijos, tačiau tai - savotiška mokslo institucijų veiklos kronika, kurioje atsispindejo tuometinès aktualijos ir visuomenès spaudimas, reikalavimas istorikams keisti tyrimu programas. Tai - lyg formali momentine „nuotrauka“.

\section{VILNIAUS UNIVERSITETO ISTORIJOS FAKULTETAS}

Vilniaus universiteto Istorijos fakultete (toliau - VU IF) 1988 m. rudeni prasidejo permainos. Profesorius Mečislovas Jučas fakulteto Tarybos posėdyje pažymėjo, kad Lietuvos istorijai tebuvo skirtas tik minimalus valandų skaičius: „prieš porą metų aš skaičiau Lietuvos TSR istorijos feodalizmo laikotarpi žymiai daugiau, t. y. tam buvo skirtas didesnis valandų skaičius negu dabar. Paskaitų požiūriu Lietuvos TSR istorija yra privesta iki minimumo, o tuo tarpu TSRS istorijos feodalizmo kursui skirta dvigubai daugiau valandų “ [44]. Netrukus ši problema bus išspręsta.

Kitas fakulteto profesorius Robertas Žiugžda informavo Tarybą apie konferenciją, skirtą „baltoms dèmėms“ visuotineje istorijoje: „Konferencijoje buvo akcentuota, jog reikia pertvarkyti visuotinès istorijos dėstymą. Reikia paskaitose paliesti tokius klausimus, kurie buvo beveik neliečiami - tai demografija, šeima, asmenybė. Dèstymas neturi būti toks dogmatiškas. Tarybinejje istoriografijoje buvo iš viso užbraukta užsienio sovietologija. Dabar 
reiktų skirstyti istoriografiją i marksistinę ir nemarksistinę, nevadinant jos buržuazine“ [42]. Tarybos pirmininkas docentas Vytautas Lesčius atkreipe dèmesị i sudètingą permainų laikotarpị: „Nelengva apžvelgti praejjusị laikotarpị, nes ką dirbome tuomet dabar gali pasirodyti netinkama. Gyvename audringu laikotarpiu, todèl kiekviena diena atneša ką nors nauja. $<\ldots>$ Mokymo procesas ir jo organizavimas vis labiau tampa sudètingas. Prasidejus persitvarkymui nelabai aišku ką daryti - buvo tik bendro pobūdžio nurodymai - mokslo tiriamojo darbo srityje, mokymo, praktikų ir pan." [45].

Visuotinès istorijos katedra prašè vietoje 1988 mokslo metų 8-ame semestre numatyto specialaus kurso „TSRS žemès ūkio socialistinis pertvarkymas ir pagrindiniai jo vystymosi bruožai iki Didžiojo Tẻvynès karo“ leisti skaityti naują specialų Algirdo Jakubčionio kursą „Tarybų Sąunga ir Europa 1922-1932 m.“ [32].

Pertvarka palietė ir universiteto struktūrą. Jungtiniame VU istorijos katedrų posėdyje nuspręsta parengti archeologijos ir etnografijos katedros atkūrimo projektą. Aleksejaus Luchtano nuomone, „etnografijos ir archeologijos katedros nebuvimas yra dalykas nenormalus. Netgi Kemerovo ir Sverdlovsko pedagoginiai institutai turi tokias katedras. Minske yra netgi specialybe்" $[40,18-20]$. Šis siūlymas buvo pateiktas Sąūdžio rèmimo grupès narių. Sigitas Jegelevičius turẻjo atskirą nuomonę VU restruktūrizacijos klausimu: „Netgi ir turint universitetui autonomiją, vargu ar tikslinga švaistytis katedromis, beatodairiškai jas likviduojant. Viena, likviduoti lengviau negu atkurti ar sukurti. Kita, kiekvienas universitetas didžiuojasi savo katedromis, jų skaičiumi, nes tai rodo (tam tikru mastu) mokymo proceso turinị bei užmojus“ $[40,18-20]$.

1988 m. lapkritị VU IF skelbimų lentoje buvo viešai paskelbtas Sąūdžio iniciatyvinès grupės tekstas, susijęs su minèta fakulteto restruktūrizacija [5]. Jis skelbė: „Istorikas turètų remtis Romualdo Ozolo įvardintais ir Lietuvos persitvarkymo sąūdžio iškeltais dvasiniam gyvenimui principais - dora, protas ir valia. <...> Atradimas savęs Didžiojoje istorijoje [gamtos ir žmonių visuomenès istorijoje] mums konkrečiai dabar negali reikštis niekaip kitaip kaip per tautos istoriją. Tai kelia uždavinị ne tik grąžinti tautai jos istoriją, bet ir surasti Lietuvą pasaulio istorijoje, mokytis „lietuviškai“ žiūrèti î pasaulio istoriją, nepaverčiant savęs „pasaulio bamba" ar nepilnavertiškumo komplekso kamuojama tauta. <...> Administracinè komandinė sistema apsprende autoritarinį, nekritišką ir dogmatinį mąstymą, o tai išgujo savarankiškumą, atsakomybę ir drąsą iš visuomenės sąmonès ir konkrečiai iš istorijos mokslo. Nepakankamas visuomenès istorinès sąmonès, tautos savimonès lygis, scientizmo ir technokratizmo vyravimas kultūroje apsprendè istorijos mokslo didžiausias bẻdas - dogmatizmą ir empirizmo dominavimą, nepakankamą demesị istoriosofijai bei teoriniam istorijos mokslo lygmeniui. $<\ldots>$ Stalininè specialisto kaip sraigtelio koncepcija, akcentuojanti ne kvalifikaciją, o politini lojalumą, vedè prie istoriko profesionalizmą ugdančių disciplinų suniveliavimo. <...> TSRS tautų istorija, įsigalint maskvocentriniam požiūriui, virto Rusų valstybės istorija, o tai savaime pavertė Lietuvos istoriją tik priedèliu prie TSRS istorijos <...>. Atsisakyti TSRS kaip Rusijos istorijos kurso, užleisti šio kurso užimamą vietą mokymo procese Lietuvos kaip Tẻvynès istorijai. $<\ldots>$ Likviduoti dabartini Istorijos fakultetą, ikuriant atskirus fakultetus pagal specialybes. Pereinamajame etape specialistų ruošimo aukščiausiais organais tampa katedros arba specialybių metodinès tarybos. <...> Sukurti Archeologijos, etnografijos ir pagalbinių istorijos disciplinų katedrą. Nota bene: visus pasiūlymus galima igyvendinti tik universitetui turint autonomiją, kurios ryžtingai ir siekiama."

III, IV ir V kursų studentai TSRS istorijos katedros vedèjui įteikè pareiškimą dèl docentès Reginos Krutulytès, kurios paskaitose „pateikiama medžiaga beveik sutampa su 
susikompromitavusiu TSKP istorijos kursu“. Nenorẻdami eiti ị kompromisus su sąžine bei tapti „stagnaciniais“ istorikais jie pareikalavo ją pakeisti. Pasirašè Mindaugas Pocius, Eligijus Raila, Arvydas Anušauskas ir daugelis kitų studentų [44]. 1989 m. vasario mèn. profesorius Raimundas Pavilonis IF Tarybos posėdyje pareiškè, kad: „TSKP istorijos katedra bus kaip Politinès istorijos katedra. $<\ldots>$ Reikès keisti katedrų politines orientacijas: darbo formas, mokymo programas" [46].

Pasiūlymai studijų programai gerinti buvo teikiami iki pat $1989 \mathrm{~m}$. pavasario semestro pabaigos. Profesorius M. Jučas IF Tarybai pranešè: „Komisija, susidedanti iš doc. S. Jegelevičiaus, prof. M. Michelberto, prof. M. Jučo, d. L. Janulevičiaus, rengè naują mokymo planą. Kadangi kuriame tautinę mokyklą, visi norime sustiprinti Lietuvos TSR istorijos dèstymą, todèl ịvesime naujus kursus. $\langle\ldots\rangle$ Vietoje ateizmo - krikščionybės istoriją Lietuvoje, nuo 9 semestro i̇vedame Lietuvos kultūros istorijos kursą, Lietuvos istorijos istoriografijos kursą skaitysime visoms specializacijoms. Nauji kursai: pagalbinès istorijos disciplinos - numizmatika, heraldika, diplomatika - tai sudetiniai Lietuvos istorijos dalykai. Taip pat bus skaitomas Lietuvos istorinès geografijos kursas, ịvedamas konstitucinès teisès pagrindų kursas" [47].

IF Komisija (Alfonsas Bacys, S. Jegelevičius, Mykolas Michelbertas, A. Luchtanas, A. Bumblauskas, R. Žiugžda) 1989 m. jungtiniame katedrų posėdyje svarstė aukštosios mokyklos pertvarkymą tautinès mokyklos pagrindu. Nutarta ịtraukti naujus kursus, išplèsti Lietuvos istorijos dėstymą, siūlyta panaikinti TSRS istorijos katedrą ir prijungti prie Visuotinès istorijos katedros, tačiau Komisija su šiuo pasiūlymu nesutiko. Katedra palikta, tik sumažinti krūviai. İtrauktas Istorijos filosofijos kursas, anot A. Bumblausko, siekiant „iveikti empirizmą“. Siūlyta atsisakyti Azijos ir Afrikos istorijos, nes, anot to paties A. Bumblausko: „Istorijos savimonés požiūriu reikètų dėstyti istoriją per Lietuvos istoriją. Istorinio mąstymo požiūriu visuotinès istorijos nèra iš viso, yra tik atskirų šalių istorija " [40, 62]. E. Gudavičius posėdyje pažymèjo: „Siekiant išugdyti gerą istorijos specialistą, mokymo procese reikètų įtvirtinti sistemą - Lietuva - Europa - Pasaulis. <...> Europos, kaip regiono, istorija turètų būti atspindèta per Lenkijos istoriją, kadangi Lietuva Europos užkampis“. Jis pasisake už religijotyros kurso, susijusio su krikščionybės istorijos kursu, dėstymą. Bronius Dundulis replikavo, kad Azija - kultūros lopšys, todẻl išbraukti Azijos ir Afrikos šalių istorijos iš mokymo proceso nepatartina [40, 63]. Pasiūlè įtraukti Prūsijos ir Mažosios Lietuvos istorijos kursą [40, 64]. Antanas Kulakauskas teige, kad TSRS istorijos kurso išvis neturètų būti, o vietoje jos - Rusijos istorija. Tam paprieštaravo A. Jakubčionis: jo nuomone, persitvarkymo sąlygomis turi ypač išaugti TSRS istorijos kurso reikšmė [40, 65].

\section{LIETUVOS ISTORIJOS INSTITUTAS}

Lietuvos TSR mokslų akademijos (toliau - MA) Prezidiumo 1987 m. gruodžio 7 d. nutarimu einančiu II direktoriaus pareigas paskirtas Ekonomikos instituto Liaudies ūkio ir ekonominės minties istorijos skyriaus vedejjas Vytautas Merkys. Tų pačių metų gruodžio $30 \mathrm{~d}$. jis išrinktas LTSR MA nariu korespondentu. LTSR MA Visuotinio susirinkimo ataskaitine sesija $1988 \mathrm{~m}$. vasario $24 \mathrm{~d}$. patvirtino V. Merki MA II direktoriumi [10]. II direktoriaus pavaduotoju moksliniam darbui nuo 1987 m. lapkričio 16 d. paskirtas Kapitalizmo istorijos skyriaus vedèjas A. Eidintas. Lietuvos TSR MA Prezidiumo 1987 m. birželio 15 d. nutarimu Lietuvos TSR MA archyvas reorganizuotas ị Lietuvos TSR centrinị mokslinị archyvą prie Istorijos instituto (skyriaus teisèmis).

1987 m. pabaigoje II dirbo 72 mokslo darbuotojai (Feodalizmo, Kapitalizmo, Socialistinès visuomenès istorijos skyriuose - 38, Mokslo ir technikos istorijos Lietuvoje 
skyriuje - 7, Archeologijos - 16, Etnografijos skyriuje - 11), iš jų 1 akademikas, 3 nariai korespondentai, iš viso 10 mokslų daktarų ir 33 mokslų kandidatai. Kandidatines disertacijas rengè 5 disertantai [10].

Anot A. E. Senno, 1988 m. kolektyvinès žmonių sąmonès sargai, sovietinès Lietuvos istorikai, pateko ị keblią situaciją. Lietuvoje oficialiąja istorija nepasitikèta kur kas daugiau negu Maskvoje. Istorikai ne tik turèjo atsiliepti ị kritiką iš viršaus, bet taip pat sužinojo, kad ir skaitytojai jais netikejjo [38, 4]. $1988 \mathrm{~m}$. vasarą ir rudenį istorija buvo ne tik praeities įvykių aprašymas, bet ir susirūpinimas tautos praeitimi bei ateitimi. Buvo keliami tautos kultūros, tradicijų ir net fizinès aplinkos išsaugojimo klausimai [38, 7]. Devintojo dešimtmečio pabaigoje tie žmonès, dabar turẻdami per penkiasdešimt metų ir gerai ịsitaisę kaip kitų profesijų atstovai, be abejonès, atsiminè jaunystejje skaitę Šapoką. Šiuo metu jie neigiamai traktavo tuos žmones, kurie sovietinejje sistemoje pasirinko profesionalo istoriko profesiją $[38,17]$. Nors J. Jurginis išskyrè MA II Lietuvos TSR istorija, kurios pirmas tomas išleistas 1985 m., daugumai lietuvių Šapokos istorija buvo „tikroji Lietuvos istorija“ (1988 m. dažnas apibūdinimas). Menininkai ir rašytojai šiuo metu jautèsi kur kas laisviau rinkdamiesi diskusijų temas, o istorikai pasiliko dalimi komandinès-administracinès sistemos, kuri iš viršaus pateikdavo savo reikalavimus ir atlygindavo už padarytą darbą [38, 18]. Partijos istorijos institutas (toliau - PII), „partinio“ konservatyvaus požiūrio branduolys, II bandè pastūmèti Lietuvos istoriją reformos link. II (Sąjūdžio pradžioje pakeitęs pavadinimą i Lietuvos istorijos institutą) turejjo teisę paskelbti planinius darbus - deja, tai buvo tik viena kita knyga per metus, išleista „Mokslo“ ar „Minties“ leidyklos. Apskritai visos leidyklos buvo kontroliuojamos, deficito laikais trūko popieriaus, leidžiama mažai $[2,28]$. A. Eidintas su V. Merkiu įtikinėjo LKP CK sekretorių ideologijai Lionginą Šepetį, kad būtinai reikia išleisti „Lietuvos istoriografijos" serijoje A. Šapokos redaguotą „Lietuvos istoriją" - nieko blogo ten nèra, istorijos žinių poreikis didelis, žmonès esamais vadovèliais ir darbais nepatenkinti. L. Šepetys sutiko, kad gal ir būtų tokia išeitis [2, 34]. V. Merkys $1988 \mathrm{~m}$. vasario $4 \mathrm{~d}$. II Mokslinès tarybos posedyje informavo, kad leidykla „Mintis“ nuo $1990 \mathrm{~m}$. pradès kas dvejus metus leisti Lietuvos Metrikos tomus po 40 a. l. Leidykla taip pat siūlo leisti senųju istorikų darbus. Tai prisidètų prie istorijos žinių plètojimo [12].

Anot A. E. Senno, istorikai jautė spaudimą iš visų pusių. Svarstant „baltas dèmes“ istorijoje valdžia teisinosi, kad istorikai rūpinosi savo reikalais. Dalis visuomenès pradejjo atvirai sakyti, kad istorikais niekuomet netikėję, nors buvo išimčių, pvz., II darbuotoja Regina Žepkaitè, atsargi ir vengusi stereotipų [38, 31]. Pati R. Žepkaitė atsiminimuose pabrèžè, kad tuo metu niekas nenorejo suprasti, koks pavojingas Sovietų Sąjungoje buvo istoriko objektyvumas $[49,78]$.

Iniciatyvos ateidavo ir iš visuomenès. A. E. Sennas mini apsukrius kooperatininkus iš leidèjų įmonès Kaune, kurie pasisiūlè II išleisti ką nors iš Lietuvos istorijos, greitai ir be jokios cenzūros, prižadejo net sumokèti honorarą autoriui, tačiau istorikai neturejo ką pateikti. Itin didelis atotrūkis tarp rašymo ir išleidimo išryškèjo tada, kai viena gamykla Vilniuje paskelbe skirsianti $1000 \mathrm{rb}$ premiją autoriui už geriausią naują Lietuvos istorijos veikalą. Istorikai apskritai nebuvo pratę sparčiai dirbti. Tuo metu spaudai rengiami veikalai buvo skubiai taisomi, kad atitiktų laiko reikalavimus [38, 90-91].

1988 m. gegužès 31 ir birželio 1 d., atsiliepdamas ị visuomenès reikalavimą, II surengè respublikos istorikų suvažiavimą. Nors organizatoriai kovo mėnesi išsiuntė 300 kvietimų istorikams, atsiliepė tik 24 [38, 31]. Henrikas Šadžius II direkcijos posėdyje pažymèjo: „Toliau vyksta demokratizavimo procesas. Istorikai atsidūrè nelengvoje padètyje. 
I kiekvieną klausimą reikia žvelgti naujai. Siūlyčiau „Lietuvos TSR Istorijos“ II tomo išleidimą metams atidèti. Reikètų daugiau pasisakyti spaudoje visuomenę jaudinančiais klausimais" [22]. Nutarta atidèti veikalo leidybą 1989 metams, daugiau skelbtis spaudoje, realiau atskleisti istorinius faktus.

1988 m. lapkričio mèn. pabaigoje II Kapitalizmo istorijos skyrius Zitą Medišauskienę ir Jūratę Marcinkevičienę rekomendavo registruoti pokariu žuvusius asmenis. Nutarta pakeisti jaunųjų istorikų premijos vardą, ìvardijant ją Igno Jonyno premija (vietoje buvusios J. Žiugždos) [11].

Kai kurie istorikai ne iškart suprato pertvarkos esmę. Solomono Atamuko monografijos rankraščio „Lietuvos TSR kadrų ugdymas 1940-1960 m. Istorinė apybraiža“ svarstymas II Socialistinès visuomenès skyriuje užstrigo. Skyriaus vadovas H. Šadžius pažymėjo: „monografijos pratarmè nevykusi, neatsako iš dabarties pozicijų i iškeltą klausimą <...> Ar galima remtis P. Cvirkos žodžiais apibūdinant buržuazinès Lietuvos politiką? Prieš keletą metų monografiją būtų galima buvę spausdinti tokią, kokia ji dabar yra, bet dabar ją reikia pertvarkyti“ [13]. Be to, S. Atamukas siūlè ị 1991 m. redakcinį planą ịtraukti „Antikomunistinių Vakarų mokslo centrų koncepcijų kritiką“ [14]. Svarstant „Tarybų Lietuvos enciklopedijos“ vardyną, S. Atamukas teigè: „vardyne neradau daugelio nusipelniusių revoliuciniam judejimui žmonių. Personalijas dar reikètų peržiūrèti“ [15].

1988 m. birželị vyko straipsnių rinkinio „Lietuvos TSR Visuomeninès organizacijos 1961-1985 metais“ rankraščio aptarimas. B. Puzinavičius pažymejjo, kad jame visai nèra medžiagos apie paminklų nykimo (be naikinimo) faktus, o juk pastaruoju metu tokios informacijos galima rasti kiekviename laikraštyje [16].

1988 m. rugsèjo mèn. pabaigoje V. Merkys pranešè, kad Socialistinès visuomenès istorijos skyriuje bus tiriama nauja tema "Migraciniai ir demografiniai procesai Lietuvoje“ ir kad tą temą tiriant nuo 1939 iki 1959 m. bus galima nušviesti daug procesų: stalininę kolektyvizaciją, deportacijas, repatriaciją ir kt. [17]. Vèlesniame lapkričio mėnesį vykusiame itin vaizdžiai permainas išreiškusiame skyriaus posėdyje Kęstutis Strumskis pareiškè: „persitvarkymas mums iškèlè daug naujų problemų. Jas dabar gana sunku aprèpti. Nacionalinių santykių problema buvo nusistovejusi ir reali, bet dabar reikia ją iš naujo peržiūrèti <...> Dar daug senųjų istorikų iki šiol tebesilaiko senųjų koncepcijų, neturi pilietinès drąsos pripažinti savo klaidas. Manau, kad kiekvienam dabar reikia rimtai viską permąstyti ir pripažinti klaidas“ [18]. Nastazija Kairiūkštytė jam antrino: „vertinant mūsų atliktus darbus, daugelis yra nepatenkinti. Mes buvome priversti rašyti taip, o ne kitaip. Neturejome galimybès diskutuoti dèl daugelio negatyvių reiškinių. Reikia pasiekti, kad istorija būtų visuomenès, o ne partijos istorija“. Algimantas Garliauskas manė, kad reikètų pradèti tirti inteligentiją. Jonas Rekešius pažymėjo, kad: „norint šiandien būti istoriku, reikia iš esmès keistis pačiam. Reikia tapti piliečiu. Aš asmeniškai noriu tyrinèti 1940-1941 m. rezistenciją“. Eugenijus Grunskis jam pritarė ir taip pat išreiškè norą tirti rezistencijos temą. Kitame posėdyje jis pasiūle savo temą: „Pasipriešinimas stalininiam režimui Lietuvoje: $1944 \mathrm{~m}$. liepa - 1945 m. gegužè [19]. Vienintelè skyriaus darbuotoja Stasė Overaitė išreiškè jau nueinančią praeitin poziciją: „reikia mums visiems vèl mokytis marksistinès metodologijos. Reikia labai rimtai įvaldyti dialektiką“. H. Šadžius konstatavo, kad skyriui reikejjo tokio apsikeitimo nuomonèmis. Jis reagavo ir ị II Sąūjžio iniciatyvinès grupès kvietimą siūlyti naujas temas: „Persitvarkyti reikia ne tik socializmo skyriui. Kiti skyriai taip pat turi labai daug problemų, „baltų dèmių“. Jas reikia tirti. Skaudu žiūrèti ị darbuotojų pasyvumą. Neišnaudojamos visos galimybès. Reikia kiekvienam rašyti ị spaudą <...> [20]. 
1989 m. vasario mèn. pabaigoje buvo išrinkta II Mokslinè taryba (V. Merkys, A. Eidintas, V. Milius), įsteigtas Archeografijos skyrius, kuris užsièmé šaltiniotyra, o pirmiausia - Lietuvos Metrikos knygų rengimu [24]. Bronius Vaitkevičius supažindino Mokslinès tarybos narius su Lietuvos TSR istorijos rengiamo II tomo būkle: „<...> smarkiai keičiantis kai kurioms koncepcijoms bei kriterijams, vertinant atskirus Lietuvos istorijos laikotarpius, reikia naujų tyrinejjimų, taip pat panaudoti naują medžiagą, kurios pastaruoju metu nemažai pasirodè ar diskusijų metu išryškejo. Keistina chronologija <... Taip pat įtraukti du naujus skyrius: Lietuvos Respublikos susidarymas 1917-1920 m. ir Lietuvių emigracija. Jų autoriais siūlytų R. Žepkaitę ir A. Eidintą <...> išryškinti Lietuvos Respublikos pasiekimus, ypač kultūros sferoje, nušviesti 1939-1940 m. slaptųjų protokolų esmę. Tikisi, kad tarybinė vyriausybẻ pareikš šiuo klausimu savo oficialią nuomonę, o jeigu ne, tai redakcija išdèstys savąją" [25].

1989 m. II Mokslinès tarybos posėdyje nutarta vadovèlius vadinti „Lietuvos istorijos“ vadovèliais [26]. Taryba svarstė labiausiai ideologizuoto Socialistinès visuomenès istorijos skyriaus, iš kurio išejo nemažai žmonių, likimą. Leonas Mulevičius siūlè pakeisti pavadinimą i Naujausių laikų Lietuvos istorijos skyrių, Albinas Visockis - pavadinti „LTSR ar Naujųjų laikų istorijos skyriumi“. H. Šadžius pabrèžè, kad sunkiai vyksta skyriaus „asmeninè pertvarka“, ketinama imtis kolektyvizacijos, migracijos temų [27].

II Mokslo ir technikos istorijos skyriuje iškilo kita problema. Algirdas Tupčiauskas II direkcijai parašè skundą dèl Algimanto Liekio vadovavimo skyriui metodų, kadangi svarbiausias skyriaus trejų metų darbas - Lietuvos mokslų akademijos istorija - „virto visų bendradarbių darbų kompiliacija“, kurią skyriaus vedejas jau teikè recenzuoti kitoms institucijoms [1]. Šią situaciją minèjo savo atsiminimuose ir tuometinis II direktorius V. Merkys, pažymėdamas, kad A. Liekis tekstą mégino taisyti, bet „kuproto ir karsto lenta neištiesins“ [30, 317].

1989 m. jau pasirodè vertingų mokslinių darbų ir disertacijų, atitinkančių naują politinę padètį ir visuomenès poreikius. Tokia buvo V. Žalio disertacija „Lietuva Baltijos Antantès sistemoje 1939-1940 metais“, labai gerai ịvertinta ir II recenzentų [23], ir kolektyvinio oponento, Vilniaus valstybinio pedagoginio instituto (toliau VPI) Lietuvos istorijos katedros, atsiliepime, kuriame pažymima, kad „Lietuvos istorijos mokslas susilaukẻ labai reikšmingo tyrinejjimo <...> Suprantama, kad tokio analitinio tyrinejjimo atsiradimas buvo galimas tik šiuo metu vykstančio šalies demokratizavimo sąlygomis, kada istorijos mokslas igauna savo tikrą moksliškumo statusą, kuomet istorinè tiesa tampa visos visuomenès, o ne atskirų privilegijuotų grupių monopoliu <...> disertantas mokslinès analizès metodo pagalba kritiškai vertina ne tik užsienio, bet ir tarybinių istorikų darbus, nes kai kurių „tiesos“ ilgus metus buvo įsitvirtinusios istoriografijoje kaip nepažeidžiamas etalonas <...> [9]. V. Žalys vieną to laikotarpio savo straipsni pradejjo taip: „Persitvarkymo ir visuomenės demokratizacijos procesas nepaliko nuošalyje ir istorikų. Nauja politinè situacija, pats gyvenimas ragina istorikus atsisakyti asmenybès kulto laikais susiklosčiusios deformuotos, dogmatinès mąstysenos, nenukrypti nuo praeities vertinimo istorizmo principo, reikalaujančio istorinị procesą suvokti kaip visumą su visais jo prieštaravimais“ [48].

Elena Vaitiekienè atsisakè toliau dirbti prie Maskvoje rusų kalba leidžiamo dokumentų rinkinio apie SSRS tautų kultūros raidą, savo pareiškime redakcinei kolegijai Maskvoje pažymėdama, kad „medžiagos atranka tikslingai niveliuojama atskirų respublikų nacionalinė kultūra" [21].

1987-1990 m. moksliniuose tęstiniuose istorikų leidiniuose kito straipsnių tematika. Antai Lietuvos istorijos metraštyje dar 1987 m. išspausdintas buvusio II direktoriaus 
(1970-1987) B. Vaitkevičiaus straipsnis buvo skirtas „Didžiosios Spalio socialistinès revoliucijos" 70-mečiui [41], o E. Gudavičiaus straipsnis pažymèjo jau kitą - Lietuvos krikšto jubiliejų [4].

Permainų metais kai kurie istorikai viešai visuomenei kalbejjo apie istorijos ir istorijos tyrimo problemas. 1988 m. gegužès 30 d. - birželio 2 d. konferencijoje (organizavo II, PII, VU IF) kasdien dalyvavo nuo 100 iki 200 žmonių [50]. Apie 1988 m. rugpjūčio 23 d. mitingą Vingio parke reporterẻ Jurga Ivanauskaite rašè: „Su didžiausia atida buvo išklausyti istorikai, kurių kalbose ne kartą nuskambejo apsivalymo ir atgailos žodžiai: „Stalinizmo neatsikratysime, kol nesuprasime, kad mokslas, taip pat ir istorija, kuriami laboratorijose ir sektoriuose, o ne suvažiavimuose ir partijos komitetuose“, - pareiškè G. Rudis“. „Istorikai turi atgailauti daugiau nei kas kitas“ - taip užbaigė L. Truska savo drąsią kalbą, kurioje Molotovo-Ribentropo paktą charakterizavo kaip ketvirtą Žečpospolitos padalijimą, vaizdžiai apibūdinęs ji „laidotuvių varpais Pabaltijo valstybių nepriklausomybei“ [6].

Laikinu istorijos mokslo problemų užpildymu A. Eidintas įvardijo skubotų straipsnių, net monografijų rašymą, taip pat 1989 m. pavasarị su Gediminu Rudžiu sudarytą straipsnių rinkinị „Naujas požiūris ị Lietuvos istoriją“, kuris po kelių mènesių jau buvo pasenęs [2, 43].

\section{PARTIJOS ISTORIJOS INSTITUTAS}

PII susitelkè ties „socializmo istorija“ Lietuvoje. Kai partijos lyderiams reikèdavo istorinès dokumentacijos ar pateisinimų, arba tik medžiagos prakalbai, institutas buvo pirma ịstaiga, i kurią jie kreipdavosi. I instituto biblioteką keliaudavo visi nauji spaudiniai iš Vakarų, ir buvo kalbama, kad kai kurie instituto darbuotojai buvo surinkę puikias asmenines bibliotekas [38, 18]. 1988 m. birželio 21 d. instituto keturiasdešimties metų jubiliejaus proga direktorè Vanda Kašauskienė pranešime pažymėjo, kad istorikų vienpusiška orientacija turèjo neigiamos įtakos partijos istorijos mokslo raidai $[38,19]$. Ji pareiškè, kad: „Šiandien laikmetis iš istorikų reikalauja didelès atsakomybès, principingumo, savo vaidmens persitvarkymo sąlygomis supratimo, sugebejjimo matyti ịvairias, kartais viena kitai prieštaraujančias tendencijas, reiškinius, operatyviai reaguoti i praktikos reikalavimus, toliau tirti aktualias istorijos mokslo problemas“ [35].

PII ataskaitoje už 1989 metus pripažinta, kad instituto veiklai įtaką padarè rinkimų i SSRS liaudies deputatus kampanija, savarankiškos LKP susikūrimas, demokratizacijos procesas, be to, leidykla „Mintis“ perèjo ị ūkiskaitą ir atsisakė leisti nuostolingus PII leidinius. Pažymèta, kad „Liaudies istorinè atmintis visada paaštrẻja lūžiniais jos gyvenimo momentais“, PII rengè įvairią medžiagą, atsakinèjo į daugkartines mokslinių institucijų, laikraščių ir žurnalų redakcijų užklausas, darbuotojai skaitė pranešimus ir paskaitas konferencijose, aktyviai dalyvavo „apskrituose staluose“, radijo ir televizijos laidose [34, 4-5]. Ričardas Čepas parengè publikaciją apie mokytojus, deportuotus iš Lietuvos vokiečių okupacijos išvakarèse [34, 15]. 1989 m. PII biblioteka tęsè fondų komplektavimą, darè fondų ekspertizę, atrinkinèjo leidinius perkèlimui iš specialių fondų i̇ viešo naudojimo fondus. Biblioteką sudarẻ bendras fondas (64. 343 bibliotekinių vienetų), JAV lietuvių leidinių fondas (4. 074 vnt.), retų spaudinių fondas, tarnybinio naudojimo literatūra (236 vnt.), lituanistinis fondas (1988 m. sudarytas iš specialių fondų - nuo 8. 767 iki 10. 914 vnt. 1990 m.). Specialūs fondai buvo du: pirmasis skirtas 1917-1944 m. literatūrai, antrasis - lietuvių emigrantų literatūrai. 21 egzempliorius knygų perduotas kitoms bibliotekoms, t. y. 15 tomų Bostone leistos Lietuvių enciklopedijos perduota MA II bibliotekai, du tomai - Lietuvos SSR Istorijos ir etnografijos muziejui [34, 20-22]. 1989 m. 
vasario mėn. ne pirmą kartą iškilo klausimas dèl dingusių archyvinių bylų. PII direkcijos posėdyje Jonas Čaplikas informavo apie sklindančias kalbas, kad „archyvas plačiai atidarė duris Sąjūdžio nariams ir išduodama medžiaga, kurios negalima išduoti“ [33]. Prieš metus, $1988 \mathrm{~m}$. vasario 22 d., PII direkcijos posėdyje buvo svarstomas klausimas dèl 99 partinių bylų dingimo ir dèl dokumentų apskaitos gerinimo. Informacija perduota Lietuvos KP Centro Komitetui, buvo parašytas laiškas, ant kurio Lietuvos KP CK sekretorius L. Šepetys uždejo rezoliuciją, kad ši klausimą būtina apsvarstyti kolektyve, nubausti, užkirsti kelią analogiškiems reiškiniams institute [36]. Posėdyje prieita nuomonè, kad šios bylos galejo dingti per ilgesni laiką, nes revizija nedaryta 40 metų.

1989 m. PII organizuotos „apvalių stalų“ diskusijos: birželio 2 d. tema „Lietuvos TSR piliečių deportacijų $1941 \mathrm{~m}$. birželio 14-17 d. priežastys ir pasekmès“, diskusiją vedè V. Kašauskienè, dalyvavo Centrinio valstybès archyvo direktorè A. Burauskaité, Česlovas Bauža, Konstantinas Surblys, J. Čaplikas, Gediminas Vaskèla, Jonas Bagušauskas; liepos 17 d. - „Molotovo-Ribentropo paktas ir tolesnis Lietuvos likimas“; rugsèjo 28 d. - „SSRS ir Lietuvos Respublikos bendradarbiavimo sutartis nuo 1939 m. spalio 10 m.", pastarojoje, be PII darbuotojų, dalyvavo Regina Žepkaitè. Reportažus apie diskusijas rodè informacinè televizijos laida „Panorama“, aprašè Vakarinés naujienos [34, 28].

\section{VILNIAUS PEDAGOGINIO INSTITUTO ISTORIJOS FAKULTETAS}

1988 m. rudeni VPI Istorijos fakultete nutarta Lietuvos TSR Istorijos katedrą pervadinti Lietuvos istorijos katedra ir dèstyti Lietuvos istorijos kursą (nutarta siūlyti tokius kursus: Lietuvos archeologija (iki feodalinių santykių atsiradimo), Lietuvių etnografija, Lietuvos istorija (iki Liublino unijos), Pagalbiniai istorijos mokslai, Lietuvos istorija (nuo Liublino unijos iki padalijimų), Šaltiniotyra, Lietuvos istorija (nuo padalijimų iki $1861 \mathrm{~m}$.), Istorijos dèstymo metodika, Lietuvos istorija (nuo 1861 iki 1918 m.), Lietuvos istorija (nuo 1918 iki 1940 m.), Lietuvos istorija (1940-1988), Lietuvos kultūros istorija, Lietuvos istoriografija); taip pat rekomenduoti rašyti kursinius darbus iš Lietuvos istorijos arba temą lituanizuojant [28]. Aldona Gaigalaitè atsimena, kad VPI dar gerokai iki Atgimimo buvo įtrauktas atskiras Lietuvos istoriografijos kursas, nors kai kurie absolventai vẻliau ir teigè, kad iš Lietuvos istorijos likdavo tik „nugraužtas kaulas“ $[3,95]$.

1989 m. katedra kartu su kitais fakulteto dèstytojais bei istorikais turèjo pabaigti rengti rankraštị „Lietuvos istorijos paskaitos ne istorijos specialybės studentams“, tačiau šis darbas nebuvo iki galo atliktas. Dèl tuo metu besikeičiančios istorinès koncepcijos nebuvo panaudota svarbi archyvinè medžiaga. A. Gaigalaitè parašè skyrių „Lietuvos ekonominè būklè 1939-1940 metais“ Lietuvos TSR MA II 1989 m. parengtam planiniam darbui - knygai Lietuva 1939-1940 metais. Remdamasi to skyriaus medžiaga ji perskaite pranešimą 1989 m. gegužès mėnesị Vilniuje ịvykusioje Pabaltijo istorikų konferencijoje. Šią konferenciją tema „Pabaltijo valstybių vidaus ir užsienio politikos problemos Antrojo pasaulinio karo išvakarèse" organizavo II.

VPI Lietuvos istorijos katedra recenzavo MA II ir VU Mokslinių tarybų pateiktas daktaro ir kandidato disertacijas (iš viso 4) [28]. 1989 m. vasario 9 d. VPI IF Lietuvos istorijos katedros kolektyvas pasiūlè „Šviesos“ leidyklos redaktoriui Stanislovui Petrauskui parengti naują mokyklinès Lietuvos istorijos chrestomatijos leidimą. Pažymèta, kad „Tautinės mokyklos šiandieniniai uždaviniai reikalauja iš esmès peržiūrèti anksčiau išleistąsias Lietuvos istorijos chrestomatijas, nes jos neatitinka šiandieninių istorijos mokslo reikalavimų“ [9]. 


\section{IŠVADOS}

Peržiūrẻjus ir įvertinus 1988-1990 m. keturių mokslo ir studijų institucijų posėdžių protokolus, galima išskirti šias užfiksuotas veiklos sritis.

VU IF buvo atkreiptas dėmesys ị per mažą valandų skaičių, skirtą Lietuvos istorijos dalykams, pertvarkytos studijų programos, pakeisti kursai, vykdyta fakulteto restruktūrizacija steigiant naujas katedras, organizuotos konferencijos istorijos „baltoms dèmèms“ aptarti, studentai teikè pareiškimus, siūlydami panaikinti susikompromitavusius ideologizuotus kursus.

II turèjo peržiūrèti leidybos planus ir mokslo programas, posėdžiuose svarstyta, kaip pertvarkyti istorijos tyrimus ir pradèti tirti naujas temas ir procesus: migracinius ir demografinius procesus, Lietuvos Respublikos susikūrimą ir jos diplomatiją, Molotovo-Ribentropo paktą, deportacijas, repatriaciją, stalininę kolektyvizaciją, rezistenciją ir kt. Pradètos ginti pirmosios disertacijos šiomis temomis, istorikai atsisakydavo dirbti bendruose projektuose su SSRS istorikais, jeigu juose buvo niveliuojama lietuvių tautos kultūra. Organizuotos konferencijos, II skyrių posėdžiuose raginama daugiau pasisakyti spaudoje, aktyvesnieji dalyvavo Sajūižio mitinguose, pasisakydavo aktualiais istorijos klausimais.

PII kaip labiausiai ideologizuota institucija taip pat turejjo reaguoti į vykstančias permainas, todèl organizuodavo "apskritų stalų“ diskusijas. Iki instituto panaikinimo jo archyve nustatyti tarnybinių bylų dingimo faktai.

VPI Lietuvos istorijos katedra recenzuodavo VU ir II mokslinių tarybų pateiktas disertacijas, pertvarkè studijų programą, teikè pasiūlymus Švietimo ministerijai dèl mokymo priemonių modernizavimo.

Gauta 20150922

Priimta 20160412

\section{Literatūra ir šaltiniai}

[1] A. Tupčiausko raštas MA Istorijos instituto direkcijai, $1988 \mathrm{~m}$. lapkričio $26 \mathrm{~d}$. Lietuvos centrinis valstybes archyvas (toliau - LCVA), f. R-1016, ap. 1, b. 658, 1. 42-43.

[2] EIDINTAS, Alfonsas. Istorija kaip politika. Ivykiu raidos apžvalgos. Vilnius: Baltos lankos, 2008.

[3] GAIGALAITĖ, Aldona. I save ir istorija pažvelgus. Vilnius: Vaga, 2002.

[4] GUDAVIČIUS, Edvardas. Lietuvos krikščionybès prièmimo politinè problema. Lietuvos istorijos metraštis. 1987 metai. Vilnius: LTSR MA Istorijos institutas, 1988, p. 14-22.

[5] Istorijos specialistų ruošimo pertvarkymo projektas, siūlomas IF persitvarkymo sajūdžio iniciatyvinès grupès, priedas prie jungtinio katedrų posèdžio protokolo Nr. 5, 1988 m. lapkričio $16 \mathrm{~d}$. Vilniaus universiteto archyvas (toliau - VUA), f. R-856, ap. 24, b. 835, 1. 28-33.

[6] IVANAUSKAITE், Jurga. Netektis - 1939, Atgimimas - 1988. Sajūdžio žinios, Nr. 30, 198808 29, p. 1.

[7] IVANAUSKAS, Vilius. Tinklaveika mokslininkų aplinkoje: tarp oficialių sovietmečio procesų ir alternatyvių požiūrių. Sajūdžio ištaku beieškant. Nepaklusniųju tinklaveikos galia. Vilnius: Baltos lankos, 2011, p. 143-149.

[8] LAURINAVIČIUS, Česlovas; SIRUTAVIČIUS, Vladas. Lietuvos istorija. Sajūdis: nuo „Persitvarkymo“ iki kovo 11-osios. T. XII, I d. Vilnius: Baltos lankos, 2008, p. 43-44.

[9] Lietuvos istorijos katedros siunčiami raštai Nr. 10 (lapai nenumeruoti). Lietuvos edukologijos universiteto bibliotekos Rankraščiu skyrius (toliau - LEUB RS).

[10] Lietuvos istorijos metraštis. 1987 metai. Vilnius: LTSR MA Istorijos institutas, 1988, p. 178. 
[11] Lietuvos TSR MA Istorijos institutas. Kapitalizmo istorijos skyrius. Posedžio protokolas Nr. 6, 1988 m. lapkričio 29 d. LCVA, f. R-1016, ap. 1, b. 644, 1. 13.

[12] Lietuvos TSR MA Istorijos institutas. Moksline taryba. Posèdžio protokolas Nr. 1, 1988 m. vasario 4 d. LCVA, f. R-1016, ap. 1, b. 643, 1. 4.

[13] Lietuvos TSR MA Istorijos institutas. Socialistinès visuomenès istorijos skyriaus posèdžio protokolas Nr. 1, 1988 m. sausio 22 d. LCVA, f. R-1016, ap. 1, b. 645, 1. 2-3.

[14] Lietuvos TSR MA Istorijos institutas. Socialistinès visuomenès istorijos skyriaus posèdžio protokolas Nr. 2, 1988 m. kovo 24 d. LCVA, f. R-1016, ap. 1, b. 645, 1. 8-9.

[15] Lietuvos TSR MA Istorijos institutas. Socialistinès visuomenès istorijos skyriaus posèdžio protokolas Nr. 4, 1988 m. balandžio 8 d. LCVA, f. R-1016, ap. 1, b. 645, 1. 2.

[16] Lietuvos TSR MA Istorijos institutas. Socialistinès visuomenès istorijos skyriaus posèdžio protokolas Nr. 7, 1988 m. birželio 23 d. LCVA, f. R-1016, ap. 1, b. 645, 1. 18-19.

[17] Lietuvos TSR MA Istorijos institutas. Socialistinès visuomenès istorijos skyriaus posèdžio protokolas Nr. 9, 1988 m. rugsejo 29 d. LCVA, f. R-1016, ap. 1, b. 645, 1. 27-28.

[18] Lietuvos TSR MA Istorijos institutas. Socialistinès visuomenès istorijos skyriaus posèzžio protokolas Nr. 10, 1988 m. lapkričio 5 d. LCVA, f. R-1016, ap. 1, b. 645, 1. 29-31.

[19] Lietuvos TSR MA Istorijos institutas. Socialistinès visuomenès istorijos skyriaus posèdžio protokolas Nr. 13, 1988 m. gruodžio 9 d. LCVA, f. R-1016, ap. 1, b. 645, 1. 38.

[20] Lietuvos TSR MA Istorijos institutas. Socialistinès visuomenès istorijos skyriaus posèzžio protokolas Nr. 11, 1988 m. lapkričio 28 d., LCVA, f. R-1016, ap. 1, b. 645, 1. 34.

[21] Lietuvos TSR MA Istorijos institutas. Socialistinès visuomenès istorijos skyriaus posèdžio protokolas Nr. 4, 1989 m. balandžio 14 d. LCVA, f. R-1016, ap. 1, b. 661, 1. 11-12.

[22] Lietuvos TSR Mokslų Akademija. Istorijos institutas. Direkcija. Posedžio protokolas Nr. 13, 1988 m. balandžio 2 d. LCVA, f. R-1016, ap. 1, b. 632, 1. 34.

[23] Lietuvos TSR Mokslų Akademijos Istorijos institutas. Kapitalizmo istorijos skyriaus posèdžio protokolas Nr. 2, 1989 m. kovo 30 d. LCVA, f. R-1016, ap. 1, b. 660, 1. 3.

[24] Lietuvos TSR Mokslų Akademijos Istorijos institutas. Mokslinès tarybos posėdžio protokolas Nr. 1, 1989 m. vasario 27 d. LCVA, f. R-1016, ap. 1, b. 658, 1. 2.

[25] Lietuvos TSR Mokslų Akademijos Istorijos institutas. Mokslinès tarybos posėdžio protokolas Nr. 2, 1989 m. kovo 23 d. LCVA, f. R-1016, ap. 1, b. 658, 1. 19.

[26] Lietuvos TSR Mokslų Akademijos Istorijos institutas. Mokslinès tarybos posėdžio protokolas Nr. 3, 1989 m. gegužès 5 d. LCVA, f. R-1016, ap. 1, b. 658, 1. 30.

[27] Lietuvos TSR Mokslų Akademijos Istorijos institutas. Mokslinès tarybos posèdžio protokolas Nr. 8, 1989 m. lapkričio 17 d. LCVA, f. R-1016, ap. 1, b. 658, 1. 71-72.

[28] LIK dèstytojų ir studentų mokslinio tiriamojo darbo ataskaita už 1989 metus, Lietuvos istorijos katedros siunčiami raštai Nr. 10 (lapai nenumeruoti). LEUB RS.

[29] LIK posèdžio $1988 \mathrm{~m}$. lapkričio 2 d., protokolas Nr. 2, Lietuvos TSR istorijos katedra. Siunčiami raštai 1988-1989 m. m. Nr. 6. LEUB RS.

[30] MERKYS, Vytautas. Atminties prošvaistès. Vilnius: Versus Aureus, 2009.

[31] MERKYS, Vytautas. Istorijos mokslo ir istorikų uždaviniai. Komunistas, 1988, Nr. 1, p. 53-58.

[32] Pažyma dèl speckurso pakeitimo, 1988 m. lapkričio 22 d. VUA, f. R-856, ap. 24, b. 816, 1. 68.

[33] PII prie LKP CK direkcijos posèdžio, įvykusio $1989 \mathrm{~m}$. vasario 11 d., protokolas Nr. 2(348). Lietuvos ypatingasis archyvas (toliau - LYA), f. 3377, ap. 60, b. 63, 1. 5.

[34] PII prie LKP CK Marksizmo-leninizmo instituto ataskaita už 1989 metus (rusų kalba). LYA, f. 3377 , ap. 60 , b. 62.

[35] PII prie LKP CK Mokslinès tarybos posèdžio, skirto Instituto įkūrimo 40-osioms metinèms 
pažymèti, țvykusio 1988 m. birželio 20 d., protokolas Nr. 2. LYA, f. 3377, ap. 60, b. 46, 1. 30.

[36] PII prie LKP CK partinio archyvo darbuotojų gamybinio pasitarimo, ịvykusio $1988 \mathrm{~m}$. vasario 26 d., protokolas Nr. 2. LYA, f. 3377, ap. 62, b. 72, 1.8.

[37] Sajūdžio žinios, Nr. 40, 198809 26, p. 1.

[38] SENN, Alfred Erich. Bundanti Lietuva. Vilnius: Mokslo ir enciklopedijų leidykla, 1992.

[39] TRUSKA, Liudas. Lietuvos persitvarkymo Sajūdžio ištakos. 1991 metu sausio 13-oji Lietuvoje naujausių moksliniu tyrimu kontekste. Vilnius: VPU leidykla, 2006, p. 26.

[40] TSRS istorijos, Lietuvos TSR istorijos bei Visuotinès istorijos katedrų jungtinis posédis, 1988 m. lapkričio 16 d. VUA, f. R-856, ap. 24, b. 824.

[41] VAITKEVIČIUS, Bronius. Lietuvių dalyvavimas Didžiojoje spalio socialistinejje revoliucijoje Rusijoje. Lietuvos istorijos metraštis. 1987 metai. Vilnius: LTSR MA Istorijos institutas, 1988, p. 5-13.

[42] VU Visuotinès istorijos katedros posédis, $1988 \mathrm{~m}$. spalio 31 d. VUA, f. R-856, ap. 24, b. 839,

1. 17.

[43] VVU IF studentų pareiškimas, 1988 m. lapkričio 18 d. VUA, f. R-856, ap. 24, b. 835, 1. 39-43.

[44] VVU IF Tarybos posèdžio protokolas Nr. 2, 1988 m. spalio 18 d. VUA, f. R-856, ap. 24, b. 816,

1. 27.

[45] VVU IF Tarybos posèdžio protokolas Nr. 3, 1988 m. lapkričio 22 d. VUA, f. R-856, ap. 24, b. $816,1.10$.

[46] VVU IF Tarybos posedžio protokolas Nr. 6, 1989 m. vasario 24 d. VUA, f. R-856, ap. 24, b. 816, 1. 74.

[47] VVU IF Tarybos posedžio protokolas Nr. 9, 1989 m. gegužès 26 d. VUA, f. R-856, ap. 24, b. 816, 1. 101.

[48] ŽALYS, Vytautas. Dèl karinio bendradarbiavimo Baltijos antantès sistemoje (1939-1940 m.). Lietuvos istorijos metraštis. 1988 metai. Vilnius: Mokslas, 1989, p. 59.

[49] ŽEPKAITĖ, Regina. Gyvenimas atiduotas istorijai. Vilnius: VPU leidykla, 2006.

[50] ŽEPKAITĖ, Regina; TARŠILOVA, Tamara; EIDINTAS, Alfonsas. Konferencija aktualiais Lietuvos TSR istorijos klausimais (pirmieji tiesos ieškojimo žingsniai). Lietuvos istorijos metraštis. 1988 metai. Vilnius: Mokslas, 1989, p. 215-221.

VALDAS SELENIS

\section{Transformation of Lithuanian academic and research institutions of history during 1988-1990 Resurgence from the Soviet Regime according to the minutes of meetings}

Summary

The period of Resurgence or Movement (Sajūdis) in 1988-1990 is one of the most important breakthrough moments in the history of Lithuania. The Soviet Empire began its road leading to collapse. It was the time to change and to purge away 'marxism' and ideological clichés from Lithuanian historical scholarship. Not everyone wanted to change but finally they had to follow the main stream. The main aim of this article is to reveal what transformations were fixed in the minutes of meetings of 
academic institutions staff members during this breakthrough period. The sources of this research are official meeting journals preserved in the Central State Archive of Lithuania and the Special Archive of Lithuania. It allows us to compare how this transformation was discussed in four academic institutions. It is some kind of a chronicle of changes in these days.

After the revision of these sources, the author comes to such conclusions. The Vilnius University Faculty of History had faced the problem of scarcity of courses devoted to the Lithuanian history and had to change the program of studies. New departments of history were established. Historians of the university organized conferences in order to discuss the most controversial and relevant historical topics. Students complained about the courses of Marxism and History of the USSR.

The Lithuanian Institute of History had to revise the research and publishing plans, to discuss how to rearrange the historical studies and to start new topics such as migrational and demographical processes, the establishment of the Republic of Lithuania and its diplomacy, the Pact of Ribbentrop-Molotov, deportations, repatriation, Stalinist collectivisation, resistence etc. The first doctoral dissertations from these new fields of research were defended. Lithuanian historians refused to work with their colleagues from the USSR if Lithuanian national culture was diminished or ignored in common academic projects. Historians became public figures, they started to organize press conferences, participated in public meetings.

The Institute of the Communist Party History, the most ideologized institution, also had to react to the changes. The institute organized the 'round table' discussions about relevant and painful historical problems and finally it was disbanded with some loss of important personal archival files. The Department of Lithuanian History at the Vilnius Pedagogical Institute played a minor role in the academic field of contemporary Lithuania but their professors reviewed the doctoral dissertations presented by the Lithuanian Institute of History and Vilnius University, rearranged the programme of studies and offered the propositions how to modernize the educational books.

Keywords: historical scholarship, Resurgence, historians, Vilnius University Faculty of History, Lithuanian Institute of History, Institute of the Communist Party History, Department of Lithuanian History at the Vilnius Pedagogical Institute, minutes of meetings 